\title{
A Brief History of Head and Neck Pathology
}

\author{
Robert E. Fechner, M.D.
}

Robert E. Fechner Laboratory of Surgical Pathology, Department of Pathology, University of Virginia Health System, Charlottesville, Virginia

Surgical pathology had its beginnings in the late 1800s. A biopsy that gained much attention was from the larynx of Crown Prince Frederick in 1887. The tissue was seen by Rudolph Virchow and the clinical management of the Prince eventuated in a highly publicized furor. During the first half of the twentieth century, numerous entities in the head and neck were described by dozens of pathologists worldwide. The information was scattered in clinical journals for radiotherapists, general surgeons, and otolaryngologists. The first book on ear, nose, and throat pathology did not appear until 1947 and by 1956 two atlases were available. The book was "Histopathology of the Ear, Nose and Throat" by Eggston and Wolff (1947), and the atlases were the first Armed Forces Institute of Pathology (AFIP) fascicle on salivary gland tumors by Foote and Frazell (1954) and "An Atlas of Otolaryngic Pathology" by Ash and Raum (1956). Clinicopathologic studies accelerated in the 1960s as laryngeal conservation therapy evolved and radiation therapy became more sophisticated. The years 1968 and 1974 mark major events for the emergence of Head and Neck Pathology into a clear-cut discipline. In 1968, Vincent J. Hyams was appointed Director of Otolaryngic Pathology at the AFIP, and 1974 was the publication date of "Tumors of the Head and Neck" by John G. Batsakis. The past 25 years have been filled with hundreds of articles on new entities and the application of fresh technology to old entities. Specialized therapeutic approaches have demanded greater diagnostic precision. This paper touches on a few representative aspects in the history of Head and Neck Pathology during the past 130 years.

Copyright (C) 2002 by The United States and Canadian Academy of Pathology, Inc.

VOL. 15, NO. 3, P. 221, 2002 Printed in the U.S.A.

Date of acceptance: September 27, 2001.

Address reprint requests to: Robert E. Fechner, M.D., Robert E. Fechner

Laboratory of Surgical Pathology, Department of Pathology, Box 214,

University of Virginia Health System, Charlottesville, VA 22908.
KEY WORDS: Carcinoma, Ear, Head and neck region, Larynx, Nose, Paranasal sinuses, Salivary gland.

Mod Pathol 2002;15(3):221-228

Publications on Head and Neck Pathology (HNP) began to appear sporadically two centuries ago, and with consistency in the early 1900s. Over a thousand references on head and neck tumors were listed in two papers in the 1930s; one citing 450 papers on the sinonasal region (1) and the other giving 600 references on salivary glands (2). Oral pathologists have contributed significantly to HNP. Their history is a major story in itself, and only a few persons can be acknowledged herein. This brief history of HNP is approached by looking at the chronology of a few selected and illustrative topics focusing on representative publications as well as institutions where pathologists specialized in HNP. The salivary glands are considered separately.

HNP prior to 1900

The earliest, albeit crude, laryngoscopes afforded the opportunity to remove tissue, and the first "polyp" is said to have been removed in 1860 (3). Morell Mackenzie, an English laryngologist, published a book in 1871 on one hundred consecutive biopsies, many of which had drawings of the microscopic images (4). Biopsy diagnosis was a new experience in the late 1800s. It was a daunting exercise as evidenced by looking at excellent, detailed drawings of microscopic images and their legends. For example, there was a broad range of microscopic features thought to be characteristic of ordinary squamous carcinoma. Tangential sections of cytologically normal epithelium and tissue embedded en face were especially vulnerable to the misdiagnosis of cancer (5) (Fig. 1).

One case illustrates the state of the art in managing a laryngeal tumor during the late 19th century. In 1887, Germany's Crown Prince Frederick was thought to have laryngeal carcinoma by his German physicians. Frederick's wife was the 


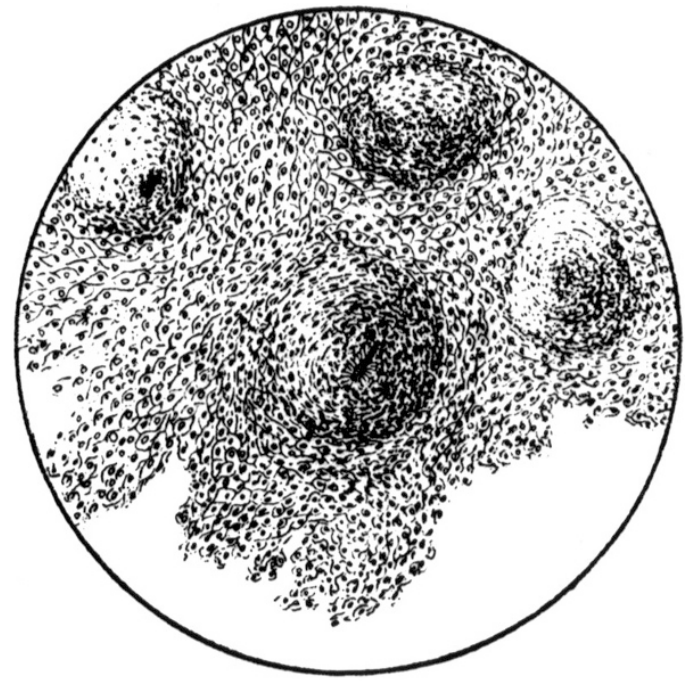

FIG. CCCXLI. -( $\frac{1}{2}$ in. Obj.)

FIGURE 1. The description for this detailed drawing of a biopsy from the larynx states that it "is composed for the most part of denselypacked stratified epithelium arranged in concentric masses ('nests'), and judging from this feature, I fear the process is malignant." To this reviewer, it looks like cytologically normal epithelium, and the nests appear to be rete pegs cut en face. Two years later without further therapy, "...the patient was in perfect health, and spoke with an absolute clear voice." (From Browne L: The Throat and Nose and Their Diseases. 1899, p. 708).

daughter of Queen Victoria and Morell Mackenzie came from England to examine the Prince. Mackenzie desired histologic proof of malignancy. He performed three biopsies that were seen by $\mathrm{Ru}$ dolph Virchow who did not see cancer. Therefore, curative surgery was not attempted. The Prince became the Emperor (Kaiser) only to die after 99 days in office. Virchow's detailed report of the biopsy indicated that no carcinoma was present (6). There are no illustrations. Virchow and Heinrich Waldeyer (of Waldeyer's ring) performed the autopsy and found subglottic cancer with nodal metastasis (7). A rancorous, public furor between Mackenzie and the German laryngologists as to who "lost" the Kaiser overshadowed any aspect of the pathology (8). Biopsy pathology was in a blastemic stage, and indeed, a preoperative tissue diagnosis was not standard for patients operated upon with a clinical diagnosis of cancer (9).

\section{HNP between 1900 and 1960}

Surgical pathology as we practice it today was rapidly evolving into the 1950s (10). Even in the 1960 s, a few surgeons were the surgical pathologists in subspecialties such as gynecology, ophthalmology, and otolaryngology (11).

During this period, many benign and malignant tumors as well as other histologic conditions were first described. The recognition of neoplasms such as rhabdomyosarcoma, myoblastoma (granular cell tumors), and subtypes of salivary gland tumors plus the characterization of noncancerous lesions such as Wegener's granulomatosis are engrossing and often labyrinthine stories unto themselves.

The period saw the publication of two fundamentally innovative concepts by Albert C. Broders, the second full-time surgical pathologist at the Mayo Clinic (Fig. 2). He defined a grading system for squamous cancer of the lip in 1920 (12), and also applied it to 362 cases of cancer of the tongue, oral cavity, pharynx, larynx, nasopharynx and paranasal sinuses (13). In 1932, Broders espoused the idea of carcinoma in situ and illustrated an example in the larynx (14). Stout briefly addressed the topic in 1952, but it was not until the 1970s that studies visited laryngeal carcinoma in situ in detail (15). This topic is still contentious, although a conceptually sound contemporary approach to preinvasive abnormalities was written by John D. Crissman and Richard J. Zarbo in 1989 (16).

Nils Ringertz in Sweden wrote a noteworthy exposition on the sinonasal region in 1938 (1). His exemplary presentation with 199 illustrations, a clinical history for each of 391 patients, and 450 references was a foretaste of more exacting clinicopathologic studies to come 25 years later.

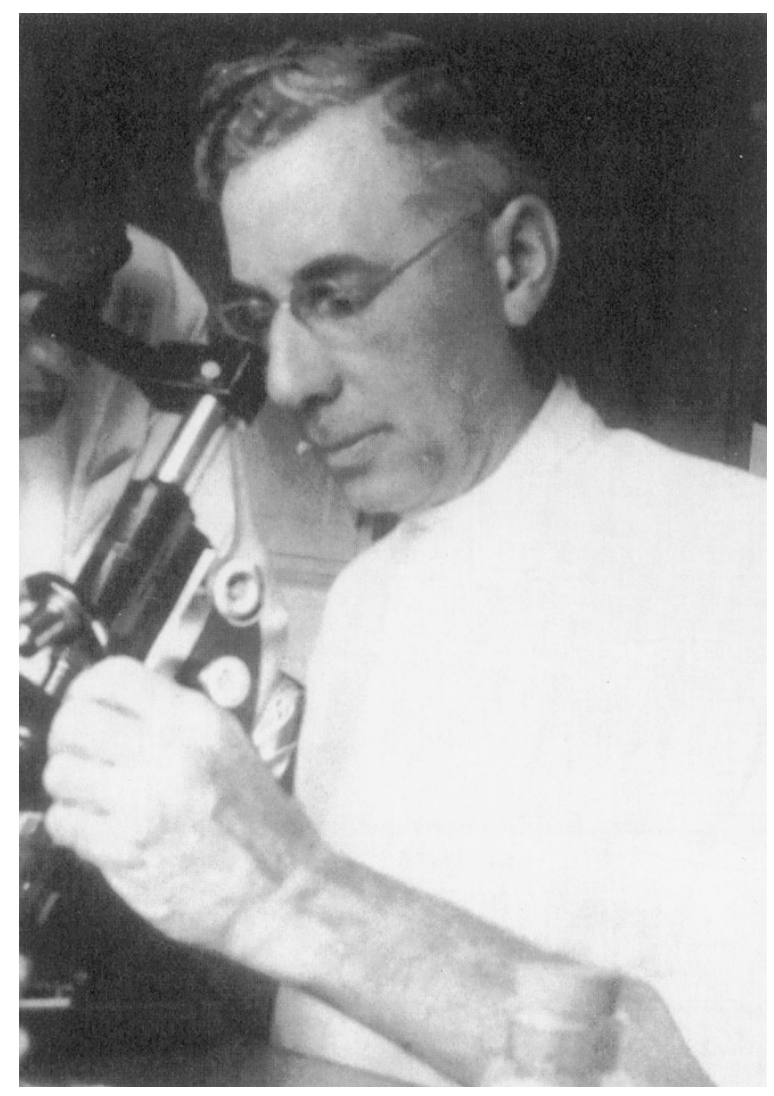

FIGURE 2. Albert C. Broders of the Mayo Clinic graded squamous carcinoma of the lip in 1920 and espoused the concept of carcinoma in situ in 1932 including carcinoma in situ of the larynx. (Used with permission. From Rosai, Guiding the Surgeon's Hand, p 158). 
The 1948 paper on verrucous cancer by Lauren V. Ackerman was a paradigm of failing to diagnose a tumor microscopically without clinical information (17). Ackerman delighted in recounting the events leading to the correct diagnosis. He had received multiple biopsies from a lesion of the oral cavity that he repeatedly called papilloma. The surgeon insisted that Ackerman see the patient who had a tumor growing from the buccal mucosa into the skin of the cheek. At the bedside, the exchange went something like this. The surgeon asked pointedly: "Now what do you think of THAT papilloma, doctor?" Ackerman replied: "Well, doctor, it still looks like a papilloma, but I must say it is the BAD kind of papilloma."

Publications that addressed multiple areas of HNP in a single volume began with the "Atlas of Otolaryngic Pathology" by James E. Ash in 1938 (Fig. 3). He was the first director of the Army Institute of Pathology (1946-1947), the forerunner of the Armed Forces Institute of Pathology (AFIP). The atlas was to help residents in otolaryngology pass the pathology section of their boards. A greatly expanded atlas with the same title appeared in 1956 co-authored by Muriel Raum who had come to the AFIP as a fellow to study HNP and then became Registrar of the American Registry of Otolaryngic Pathology (18). In addition to the larynx, sinonasal region, and salivary glands, chapters covered the esophagus, tracheobronchial tree, and lung; reflective of the role of laryngologists as the premier

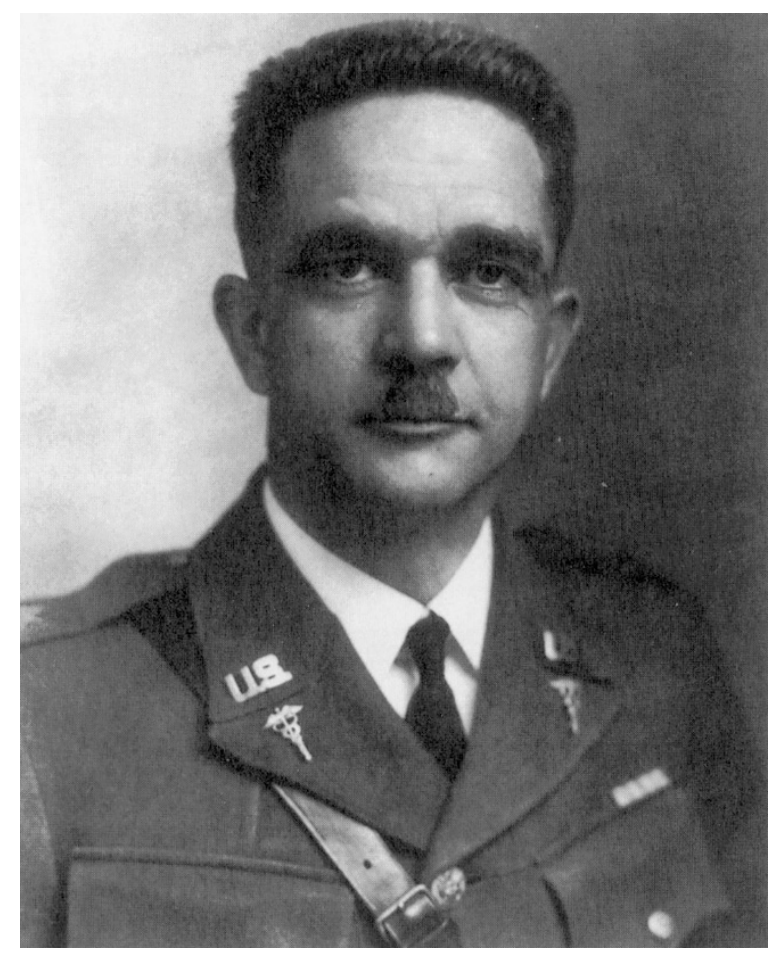

FIGURE 3. James E. Ash wrote an atlas on otolaryngic pathology in conjunction with Muriel Raum (1956) and was the senior author on the first AFIP fascicle on the upper respiratory tract (1964). (Used with permission. From Rosai, Guiding the Surgeon's Hand, p. 184). endoscopists of their day. The atlas, in the style of its time, consisted almost exclusively of photographs; clinical information was anecdotal and the text was brief. As an aside, Ash was the senior author of the first AFIP tumor fascicle on the upper respiratory tract in 1964 (19).

The first textbook on HNP, "Histopathology of the Ear, Nose and Throat" appeared in 1947 by Andrew Eggston a pathologist at the Manhattan Eye and Ear Hospital and an anatomist Dorothy Wolff (20). Eggston wrote 600 pages of the 1080 page book. The pathology of infectious diseases occupies 370 of those pages; the main area of his writing in the periodical literature. It reflects the predominant clinical concern of otolaryngology in the preantibiotic era. The remaining 400 pages written by Wolff covered embryology, gross anatomy, and histology in authoritative and exhaustive detail. She later coauthored a textbook on temporal bone pathology, and her work continues to be viewed with great respect by otologists. (Goldstein, Jerome C. Personal communication, 2000)

\section{HNP after 1960}

Early in this time frame, increasingly greater demands were made on pathologists in HNP as the old-time otolaryngologist became replaced by the full-fledged head and neck surgeon (21). The transformation is detailed in "The Head and Neck Story"; a book on the formation of the American Society For Head and Neck Surgery in 1959 (22). A few surgeons who spearheaded this transformation had experience in pathology. Joseph H. Ogura at Barnes Hospital had had two years of pathology training (11), and John J. Conley (considered by most as the father of modern head and neck surgery) "checked" the frozen sections done by the pathologists at Columbia $\mathrm{P} \& \mathrm{~S}$ during the week and did his own on the weekend. (Fu, Yao Shi. Personal communication, 2000) One otolaryngologist, John A. Kirchner (Chair of Otolaryngology at Yale) serially blocked one hundred total laryngectomy specimens in his search for the pathways that cancer spread (23). One critical observation was that supraglottic carcinomas did not cross the ventricle. This finding bolstered conservation therapy, which was in its infancy.

Surgical pathology had become a major pillar of pathology by 1960. The new "pathology of the living" demanded clinical relevance, and several institutions around the world fostered a conducive atmosphere. Under the aegis of Ackerman, Barnes Hospital in St. Louis was a good example (Fig. 4). In the early 1960s, the application of meticulous clinicopathologic correlation was firmly imprinted on HNP by Walter C. Bauer and Malcom G. McGavran at Barnes Hospital. Long-term follow-up coupled with criteria-oriented pathology characterized the 
paper on keratosis of the larynx written in conjunction with the aforementioned Ogura (24). Their studies on resected laryngeal cancers were exemplary in ways that are take for granted in papers written today: namely (1) correlation of pathologic features of the cancer with nodal status, and (2) correlation of the pathologic findings with patient outcome (25). As one example, they found that squamous cancer in various compartments of the larynx had different risks of lymph node metastases; information that altered elective neck dissections depending on clinical findings and pathologic features in the biopsy.

The collegial interaction of pathologists and clinicians was conspicuous at the Centennial Conference on Laryngeal Cancer held in Toronto in 1974. Its name honored the 100th anniversary of the first laryngectomy for cancer performed by Theodor Billroth in Vienna. Five of the 15 major sessions had pathology as the main theme (26). Presenting pathologists were: Imre Friedmann and Leslie Michaels (England), Per A. Jakobsson (Sweden), A.W. Peter van Nostrand (Canada), John G. Batsakis, Walter C. Bauer, Robert E. Fechner, H. Russell Fisher, Vincent J. Hyams (all from the United States).

The new head and neck surgeons placed a high value on pathology. For example, a three day program given in 1979 was entitled "Workshop: Pathology of the Head and Neck" and was co-sponsored by the American Society for Head and Neck Surgery and the American Academy of Otolaryngology. It was organized by Jerome C. Goldstein, a head and neck surgeon instrumental in keeping pathology as a major theme in both of these clinical societies for many years. Otolaryngologists also attended weeklong workshops on Head and Neck Pathology given by the American Society of Clinical Pathologists during the 1970s and 1980s. The formation of the American Registry of Otolaryngic Pathology at the AFIP was initiated and funded by otolaryngologists. This and other cooperative projects with pathologists have been documented in detail (27).

The interaction of pathologists with the head and neck surgical community is evident in the clinical journals. Pathologists have been members of the editorial boards of several clinical journals. Probably the longest involvement by pathologists has been with the Archives of Otolaryngology Head and Neck Surgery. In 1969, Fechner was appointed to the editorial board, and Batsakis has served since 1980. One section of the journal has had pathology case discussions since the 1950s; edited for many years by otolaryngologists. From 1969 until 1985, this section was edited by Fechner and since then by Frederic B. Askin and William H. Westra at Johns Hopkins. The cover of the journal often features a microscopic or gross pathology image and a teaser question or fragment of history from this pathology forum.

The years 1968 and 1974 mark major events for the final emergence of HNP into a fully mature discipline. In 1968 Vincent J. Hyams was appointed Director of Otolaryngic Pathology at the Armed Forces Institute of Pathology, and 1974 was the publication date of "Tumors of the Head and Neck" by John G. Batsakis (28). These two men and the institutions that they brought to the forefront in HNP will be considered individually.

\section{Vincent J. Hyams, M.D. (1924-1998)}

The Department of Otolaryngic Pathology was formed at the AFIP in 1966, and in 1968 Vincent J. Hyams became director (Fig. 5). He remained in that capacity until retirement from the Navy in 1984, after which he continued to actively practice as a Distinguished Scientist of the American Registry of Pathology until 1988. Hyams' impact on HNP cannot be overstated. His breadth of knowledge and diagnostic eye were legendary. The consultation practice was known not only for its excellence but its promptness; Hyams understood a patient's anxiety awaiting a diagnosis.

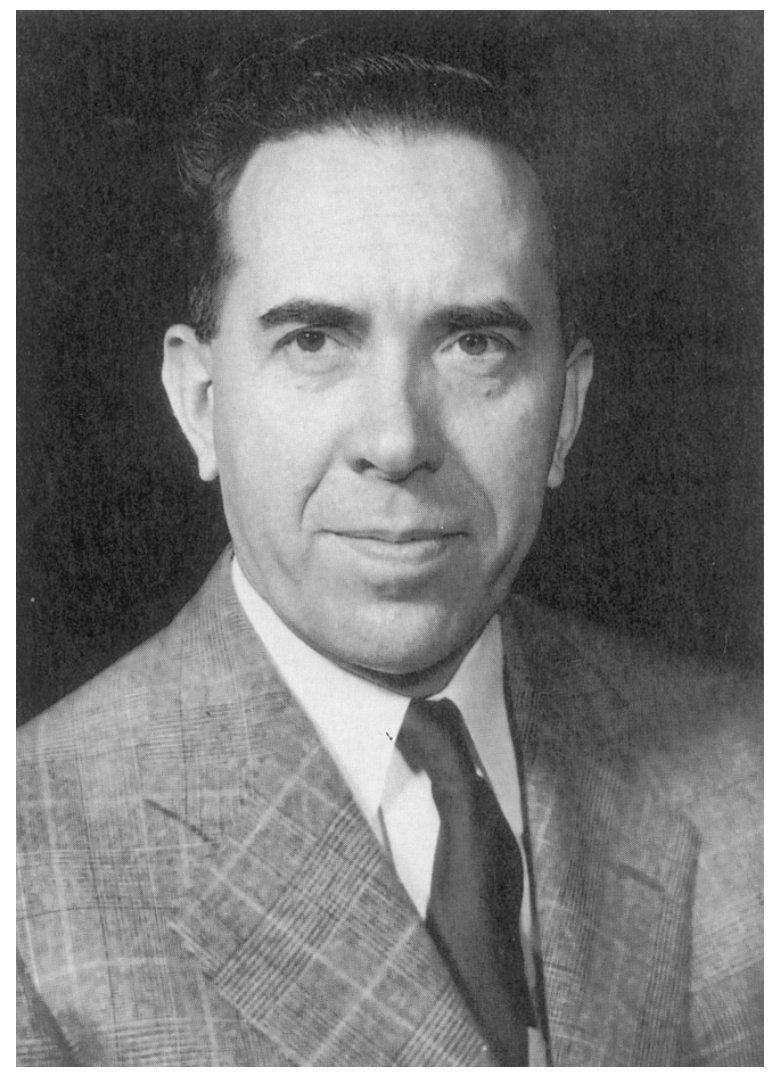

FIGURE 4. Lauren V. Ackerman described verrucous carcinoma in 1948. This photograph from 1949 was at the time he went to Barnes Hospital in St. Louis. It became a center of excellence for clinicopathologic studies on the head and neck, especially the larynx. (Used with permission. From Rosai, Guiding the Surgeon's Hand, p. 129). 
He was easily approachable and shared his broad knowledge in many ways. During the early 1970s the NIH supported civilians who wished to spend three months in otolaryngic pathology at the AFIP. Hyams organized and participated in many courses at the AFIP for pathologists and otolaryngologists. Pathology occupied two weeks of a six-week Basic Science Course in Otolaryngology that was given for several years to all military residents in otolaryngology. The interest and understanding of pathology that he inculcated in the surgical community was a phenomenon unto itself as he came to know hundreds of otolaryngologists.

Pathologists were always welcome at the AFIP. They could utilize the material as "corresponding" investigators. Douglas R. Gnepp, Jerome B. Taxy, and Richard J. Zarbo were among many who availed themselves of these opportunities. Hyams authored classical papers on middle ear adenomas and Schneiderian papillomas $(29,30)$. He was senior author on the second fascicle "Tumors of the Upper Respiratory Tract and Ear” with John G. Batsakis and Leslie Michaels (31).

At the podium, Hyams was in a class by himself. He had an enthusiastic but informal air that was disarming and belied his depth of knowledge. Who else, then or now, could spend an hour on the pathology of the ear and hold the full interest of the audience?

Hyams' legacy has carried into the 21st century at the AFIP. Dennis K. Heffner joined the AFIP in 1979, succeeded Hyams as Director, and continues a first rate consultation service. He has written many papers on HNP; some in conjunction with Hyams and more recently with Bruce M. Wenig and Lester D.R. Thompson.

\section{John G. Batsakis, M.D.}

In 1974, Batsakis' "Tumors of the Head and Neck" was the first book by a pathologist on multiple head and neck organs since Eggston and Wolff in 1947. The volume was not "how to make the diagnosis," but connected broad strokes of pathology with crucial clinical ramifications. The subtitle, "Clinical and Pathological Considerations," pointedly highlighted the multidisciplinary approach to cancer patients that was beginning its ascendancy. The imprimatur of Batsakis infused the word clinico-pathologic with a permanent energy that covered even more subjects in the second edition in 1979 (32).

In 1981, Batsakis became Chair of Pathology at the University of Texas M.D. Anderson Cancer Center in Houston (Fig. 6). As Batsakis recalls: "The seeds for new developments in head and neck pathology could be found in what had gone before. Radiation Oncology and Head and Neck Surgery had put together a single, directed totality instead of congeries of clinical

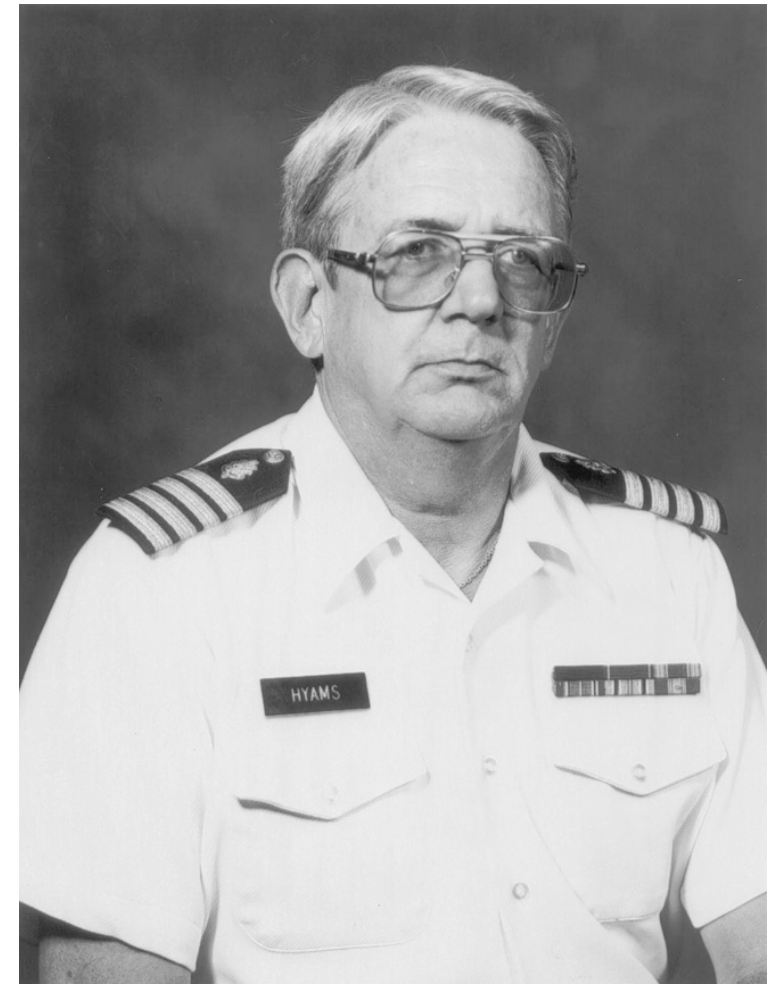

FIGURE 5. Vencent J. Hyams was director of the Otolaryngic Pathology branch of the Armed Forces Institute of Pathology from 1968 to 1984 and remained on the staff as Distinguished Scientist of the American Registry of Pathology until 1988. His style and magnitude of teaching remains unparalleled. (Photograph courtesy of Dennis K. Heffner, M.D.).

and therapeutic events. Head and neck pathology became a welcome and equal partner. Certainly other models were around for emulation; especially at the University of Virginia, Charlottesville and Fechner's surgical pathology unit. But, already in place at M.D. Anderson were: 1) the large number of annual head and neck accessions, 2) a library of tissue back to the founding of the institution, 3) an excellent followup unit; a pathology polymath in Bruce Mackay, also one of the world's finest electron microscopists, 4) superb tissue techniques, and 5) one of the early head and neck pathologists, the tireless and dedicated Mario A. Luna. To these were quickly added immunohistochemistry under Nelson Ordonez, and an ever enlarging molecular pathology section that rapidly provided translational research to patient care, all under the direction of Adel K. el-Naggar. The two investigative categories, clinical correlation and molecular head and neck pathology, kept pace with each other until the mid-90s when the latter became predominant. This change, in part, was fostered by the growing interest and then, joint participation with, head and neck pathology by chemo-prevention programs in Head and Neck Medical Oncology, gene therapy in Head and Neck Surgery, Epidemiology, and three molecular basic science departments. Molecular Genetics, Molecular Biology, and Molecular Biochemistry." (Batsakis, John G. Personal communication, 2001) 
The multifaceted activities in HNP at M.D. Anderson continue to serve as a model for studying any anatomic site by surgical pathologists in the year 2002. In the last two decades, pathologists at this institution published more than two hundred papers on HNP, many with surgeons, radiotherapists, diagnostic radiologists, and clinical oncologists.

Numerous pathologists from many other institutions have written substantive papers on HNP; especially in the last quarter century. Many diagnostic entities did not exist 25 years ago, although they are now in everyday differential diagnoses such as myospherulosis, an iatrogenic process. Nasal hemangiopericytoma-like tumors, basaloid squamous cell carcinoma, and sinonasal undifferentiated carcinoma are representative reminders of "new" neoplasms. Pseudoneoplasms include tumefactive fibroinflammatory lesion and necrotizing sialometaplasia. Finally there are lesions that do not clearly declare themselves as neoplastic or hyperplastic; sinonasal adenomatoid hamartoma is an example.

Pathologists, not mentioned elsewhere in this paper, who have contributed to HNP in the United States are hereby listed with total certainty that many who have made noteworthy observations have been

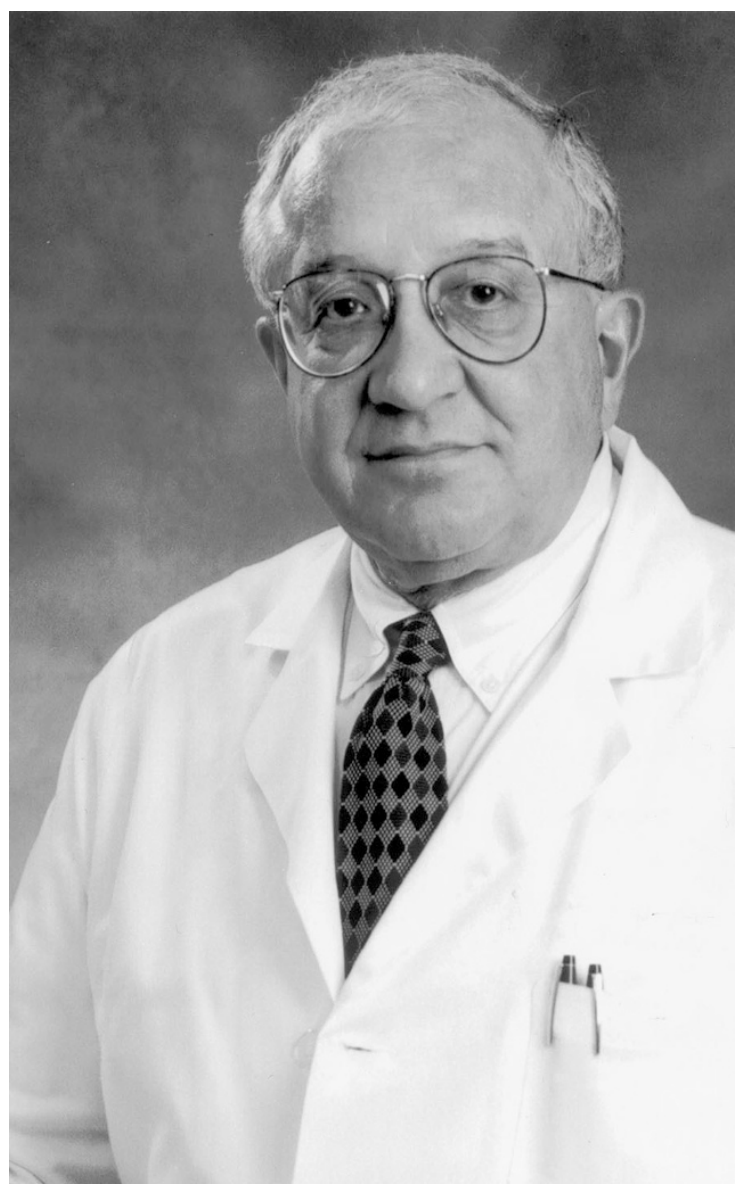

FIGURE 6. M.D. Anderson Cancer Center became a model of clinical and translational research in head and neck pathology under the leadership of John G. Batsakis, M.D. left out. A few are retired, and two are deceased (Max Goodman and Michael J. Gaffey). In several instances, the person is no longer at the designated institution where their major activities in HNP were carried out. Pathologists include: Karl H. Perzin and Yao Shi Fu (Columbia Physicians and Surgeons), Leon Barnes (University of Pittsburgh), Max Goodman and Ben Z. Pilch (Massachusetts Eye and Ear Infirmary), John D. Crissman (University of Cincinnati and Henry Ford Hospital), Lewis B. Woolner and Louis H. Weiland (Mayo Clinic), Kenneth D. McClatchey (University of Michigan and Loyola University), Margaret S. Brandwein (Mount Sinai School of Medicine), Stacey E. Mills, Henry F. Frierson, Jr, and Michael J. Gaffey (University of Virginia).

\section{Salivary Gland Pathology}

An extensive analysis of the literature on salivary gland tumors was published in 1935 by the Swedish radiotherapist Ahlbom (2). One chapter coped almost exclusively with tumor histogenesis and referred to roughly 100 papers. Pathologists 70 to a 100 years ago were deeply concerned with histogenesis of tumors including the "cell of origin" and the role of embryonic remnants. Pleomorphic adenomas were especially mischievous. No wonder pathologists from France, Germany, Finland, Italy, Spain, and the Scandinavian countries spawned a large literature on enchondromas, myxomas, and myxochondrocarcinomas without recognizing a common thread. Authors struggled with intricate machinations to explain the appearance of these and other tumors that failed to resemble any developmental or normal component of the salivary gland. Many of the intellectual exercises may seem to represent misguided energy today, but they were necessary steps in the painfully slow process of categorizing salivary gland tumors.

In 1953, Frank W. Foote, Jr. (pathologist) and Edgar I. Frazell (head and neck surgeon) published their experience on 877 patients treated by surgery at Memorial Hospital for Cancer and Allied Diseases (33). The paper contained 179 illustrations. In 1954, with essentially no alteration, the paper became the first atlas devoted to tumors of the major salivary glands in the initial series of the AFIP tumor fascicles (34). The authors thoroughly discussed terminology including the category of mucoepidermoid tumors, a term coined in a previous publication from Memoral. Interestingly, it was one of only two publications on salivary gland tumors from Memorial before the fascicle. Since the 1950s, thousands of additional patients with salivary gland tumors have been treated at this institution and have been the source of many studies. Andrew G. Huvos has been the pathologist on most publications, and he has presented many programs on the topic at pathology meetings. 
The second edition of the AFIP fascicle on major salivary glands appeared in 1974. During the 20 years since the first fascicle, a moderately large literature had been generated. Joseph L. Bernier and Albert M. Abrams from the Oral Pathology Department of the AFIP had written extensively. CarlMagnus Eneroth, Carl Blanck, Per A. Jacobbson, and J. Gunnar Moberger in Sweden wrote superb clinicopathologic studies. Gerhard Seifert in Germany published on non-neoplastic diseases as well as tumors. Some of these papers were incorporated into the book from England by Raymond W. Evans and Alan H. Cruickshank who added their own thoughts in a monograph published in 1970 (35). All of these authors were quoted in the 1974 fascicle by the English pathologist A.C. Thackray and an oral pathologist R.B. Lucas (inexplicably, their first names were never given) (36).

Gary L. Ellis D.D.S. and Paul L. Auclair D.M.D. of the Oral Pathology Branch of the AFIP (37) wrote the most recent AFIP fascicle on salivary gland tumors. It was published in 1996 and for the first time includes the minor salivary glands. The length of the atlas, the new entities, and the number of references emphasize the fact that more was published on salivary glands between 1974 and 1996 than in any other comparable time frame. A Medline search of "salivary gland neoplasms" in January, 2001 yielded 6,353 papers since 1966. Controversies on histogenesis of tumors such as the role of the myoepithelial cells still abound (38).

The explosion that occurred in the literature on salivary gland tumors after 1974 is due to several factors. One is related to the tens of thousands of salivary gland tumors that had come under coverslips by then. If a tumor (call it tumor ZX) comprised $0.5 \%$ of salivary gland tumors, there were several dozen in captivity in one place or another. If two or more ZX were in the same laboratory, an alert pathologist might recognize their commonality. In addition, a pathologist who had a slide of ZX sent to him in consultation might realize that he had a ZX in his own laboratory. Either way, a "new" entity could be created. Even for familiar, well described tumors, immunohistochemistry, cytogenetics, cytomorphic morphometry, and molecular pathology are adding new dimensions.

Tumors have been the main subject of salivary gland disease, but a few pathologists also have been concerned with non-neoplastic disease such as Seifert. Along with clinical colleagues, he published a book in 1986 on all aspects of salivary gland disease (39). The volume on salivary glands by Ellis, Auclair and Gnepp also has extensive sections on nonneoplastic diseases including developmental abnormalities (40). Non-neoplastic as well as neoplastic salivary gland lesions were the focus of a recently published monograph from France on fine needle cytopathology (41).

\section{SUMMARY}

We begin the 21st century with an incredibly enormous bank of information on head and neck pathology at our fingertips. Contrast our current bookshelf with the shelf in 1970 that contained only four volumes: Eggston and Wolff (1947), the first AFIP fascicle on salivary glands (1954), the atlas by Ash and Raum (1956), and the monograph on salivary glands by Evans and Cruikshank (1970). In addition to the publications on salivary glands mentioned in the previous section, we presently have several books where authors have addressed other components of HNP. There are works from England: "Pathology of Granulomas and Neoplasms of the Nose and paranasal Sinuses" by Imre Friedmann and David A. Osborn in 1982 (42) and Leslie Michaels' "Ear, Nose, and Throat Histopathology" in 1987 (43). In the United States, Leon Barnes published the first edition of his encyclopedic "Surgical Pathology of the Head and Neck" in 1985 and a second edition in 2000 (44). Hellquist from Sweden wrote "Pathology of the Nose and Paransal Sinuses" that came out in 1990 (45). Alberto Ferlito of Italy published "Neoplasms of the Larynx" in 1993 (46). Bruce M. Wenig wrote "Atlas of Head and Neck Pathology" in 1993 (47). "Head and Neck Pathology with Clinical Correlations" by Yao Shi Fu and Bruce M. Wenig (pathologists) and Elliot Abemayor and Barry Wenig (head and neck surgeons) has recently appeared (48). Douglas R. Gnepp has edited "Diagnostic Surgical Pathology of the Head and Neck" which came out in 2000 (49). A lifelong collaboration between a head and neck surgeon and a pathologist is seen in "Surgical pathology of the head and neck" by Dale H. Rice, Chair of Otolaryngology - Head and Neck Surgery at University of Southern California, and John G. Batsakis (50). Ben Z. Pilch has written "Head and Neck Surgical Pathology (51). Stacey E. Mills, Michael J. Gaffey, and Henry F. Frierson, Jr. wrote the 3rd series of the AFIP fascicle on "Tumors of the Upper Aerodigestive Tract and Ear" published in 1999 (52). The publications attest to the extraordinary growth of head and neck pathology in the last quarter century. The establishment of the North American Society of Head and Neck Pathology as well as fellowships in HNP (such as the one by Leon Barnes) ensure the vitality of HNP as a fruitful area of study for decades to come.

\section{REFERENCES}

1. Ringertz N. Pathology of malignant tumors arising in the nasal and paranasal cavities and maxilla. Acta Otol Laryngol (Suppl 27) 1938. 
2. Ahlbom HE. Mucous- and salivary-gland tumours. A clinical study with special reference to radiotherapy, based on 254 cases treated at Radiuhemmet, Stockholm. Acta Radiologica (Suppl 23) 1935.

3. Stevenson RS, Guthrie D. A history of oto-laryngology. Baltimore: Williams \& Wilkins; 1949. p. 104.

4. Mackenzie M. Essay on growths in the larynx: with reports, and an analysis of one hundred consecutive cases treated by the author. Philadelphia: Lindsay \& Blakiston; 1871.

5. Browne L. The throat and nose and their diseases. London: Bailliere, Tindall and Cox; 1899.

6. Virchow R. Professor Virchow's report on the portion of growth from the larynx of H.I.H. the Crown Prince of Germany by Dr. M. Mackenzie on June 28th. Br Med J 1887;2:199.

7. Schweig H. Case of Emperor Frederick III. Full official reports by the German physicians and by Sir Morell Mackenzie. New York: Edgar S. Werner; 1888.

8. Mackenzie M. The fatal illness of Frederic the noble. London: Sampson Low, Marston, Earle \& Rivington Ltd; 1888.

9. Ober WB. The case of the Kaiser's cancer. Pathol Annu 1970;5:207-16.

10. Fechner RE. The birth and evolution of American surgical pathology. In: Rosai J, editor. Guiding the surgeon's hand. The history of American surgical pathology. Washington, DC: American Registry of Pathology. Armed Forces Institute of Pathology; 1997. p. 7-21.

11. Dehner LP, Kissane JM. Surgical pathology at the Washington University medical center and Barnes hospital. In: Rosai J, editor. Guiding the surgeon's hand. The history of American surgical pathology. Washington, DC: American Registry of Pathology. Armed Forces Institute of Pathology; 1997. p. 136.

12. Broders AC. Squamous cell cancer of the lip: a study of five hundred and thirty-seven cases. JAMA 1920;74:656-64.

13. Broders AC. Epithelioma of cavities and internal organs of the head and neck. Arch Surg 1925;11:43-73.

14. Broders AC. Carcinoma in situ contrasted with benign penetrating epithelium. JAMA 1932;99:1670-4.

15. Bauer WC, McGavran MH. Carcinoma in situ and evaluation of epithelial changes in laryngopharyngeal biopsies. JAMA 1972;221:72-5.

16. Crissman JD, Zarbo RJ. Dysplasia, in situ carcinoma, and progression to invasive squamous cell carcinoma of the upper aerodigestive tract. Am J Surg Pathol 1989;13:S1-5.

17. Ackerman LV. Verrucous carcinoma of the oral cavity. Surgery 1948;23:670-8.

18. Ash JE, Raum M. An atlas of otolaryngic pathology. Washington DC: American Academy of Ophthalmology and Otolaryngology, American Registry of Pathology, Armed Forces Institute of Pathology; 1956.

19. Ash JE, Beck MR, Wilkes JD. Tumors of the upper respiratory tract and ear. Atlas of tumor pathology. 1st series. Fascicle 12-13. Washington, DC: Armed Forces Institute of Pathology; 1964.

20. Eggston A, Wolff D. Histopathology of the ear, nose and throat. Baltimore: Williams \& Wilkins; 1947.

21. Martin H. Surgery of head and neck tumors. Philadelphia: Hoeber-Harper; 1957.

22. Sisson GA. The head and neck story. Chicago: Kascot Media, Inc.; 1983.

23. Kirchner JA. One hundred laryngeal cancers studied by serial section. Annu Otol Rhinol Laryngol 1969;78:689-709.

24. McGavran MH, Bauer WC, Ogura JH. Isolated laryngeal keratosis. Its relation to carcinoma of the larynx based on a clinico-pathologic study of 87 consecutive cases with longterm follow-up. Laryngoscope 1960;70:932-51.

25. McGavran MH, Bauer WC, Ogura JH. The incidence of cervical lymph node metastases from epidermoid carcinoma of the larynx and their relationship to certain characteristics of the primary tumor. Cancer 1961;14:55-66.
26. Alberti PW, Bryce DP, editors. Workshops from the centennial conference on laryngeal cancer. New York: Appleton-Century Crofts; 1976.

27. Pratt LW, Goldstein JC, Bryans SA. A century of excellence. A 100th anniversary history of the American Academy of OtolaryngologyHead and Neck Surgery and its predecessor organizations. Alexandria, VA: American Academy of Otolaryngology-Head and Neck Surgery Foundation, Inc.; 1996.

28. Batsakis JG. Tumors of the head and neck. Clinical and pathological considerations. Baltimore: Williams \& Wilkins; 1974.

29. Hyams VJ, Michaels L. Benign adenomatous neoplasm (adenoma) of the middle ear. Clin Otolaryngol 1976;1:17-26.

30. Hyams VJ. Papilloma of the nasal cavity and paranasal sinuses. Annu Otol Rhinol Laryngol 1971;80:192-207.

31. Hyams VJ, Batsakis JG, Michaels L. Atlas of tumor pathology: Tumors of the upper respiratory tract and ear. 2nd series. Fascicle 25. Washington, DC: Armed Forces Institute of Pathology; 1988.

32. Batsakis JG. Tumors of the head and neck. Clinical and pathological considerations. 2nd ed. Baltimore: Williams \& Wilkins; 1979.

33. Foote FW Jr, Frazell EL. Tumors of the major salivary glands. Cancer 1953;6:1065-133.

34. Foote FW Jr, Frazell EL. Tumors of the major salivary glands. 1st series. Fascicle II. Atlas of Tumor Pathology. Washington, DC: Armed Forces Institute of Pathology; 1954.

35. Evans RW, Cruickshank AH. Epithelial tumours of the salivary glands. Philadelphia: WB Saunders; 1970.

36. Thackray AC, Lucas RB. Tumors of the major salivary glands. 2nd series. Fascicle 10. Atlas of Tumor Pathology. Washington, DC: Armed Forces Institute of Pathology; 1974.

37. Ellis GI, Auclair PL. Tumors of the salivary glands. 3rd series. Fascicle 17. Atlas of Tumor Pathology Washington, DC: Armed Forces Institute of Pathology; 1996.

38. Dardick I. Color atlas/text of salivary gland pathology. New York: Igaku-Shoin Med Pub; 1996.

39. Seifert G, Miehlke A, Haubrich J, Chilla R. Diseases of the salivary glands. Pathology-Diagnosis-Treatment-Facial Nerve surgery. Stuttgart: Georg Thieme Verlag; 1986.

40. Ellis GL, Auclair PL, Gnepp DR (editors). Surgical pathology of the salivary glands. Philadelphia: WB Saunders Co.; 1991.

41. Klijanienko J, Vielh P. Salivary gland tumours. New York: Karger; 2000.

42. Friedmann I, Osborn DA. Pathology of granulomas and neoplasms of the nose and paranasal sinuses. Edinburgh: Churchill Livingstone; 1982.

43. Michaels L. Ear, nose, and throat histopathology. London: Springer-Verlag; 1987.

44. Barnes L (editor). Surgical pathology of the head and neck. 2nd Ed. New York: Marcel Dekker; 2000.

45. Hellquist HB. Pathology of the nose and paranasal sinuses. London: Butterworths; 1990.

46. Ferlito A. (editor). Neoplasms of the larynx. New York: Churchill Livingstone; 1993.

47. Wenig BM. Atlas of head and neck pathology. Philadelphia: WB Saunders Co.; 1993.

48. Fu YS, Wenig BM, Abemayor E, Wenig B (editors). Head and neck pathology with clinical correlations. Philadelphia: Churchill Livingstone; 2000.

49. Gnepp DR (editor). Diagnostic surgical pathology of the head and neck. Philadelphia: WB Saunders; 2000.

50. Rice DH, Batsakis JG. Surgical pathology of the head and neck. Philadelphia: Lippincott Williams \& Wilkins; 2000.

51. Pilch BZ. Head and neck surgical pathology. Philadelphia: Lippincott Williams \& Wilkins; 2000.

52. Mills SE, Gaffey MJ, Frierson HF Jr. Tumors of the upper aerodigestive tract and ear. 3rd series. Fascicle 26. Atlas of Tumor Pathology Washington, DC: Armed Forces Institute of Pathology; 2000. 